\title{
Strategic Marketing Communication: The Case For SMME Development
}

Ms. I.T. Lisita, North-West University, South Africa

Prof. J.J. Prinsloo, North-West University, South Africa

Prof. T.G. Pelser, North-West University, South Africa

\begin{abstract}
Strategic marketing communication is imperative for the successful implementation of projects of developmental corporations. Business development in the North West Province, South Africa however, seems to be hampered by the lack of effective marketing communication from the NWDC regarding its support services and the lack of feedback from the registered SMMEs regarding their satisfaction with services rendered. This study was aimed at determining whether effective strategic marketing communication exists between the North West Development Corporation $(N W D C)$ and all their registered Small, Medium and Micro Enterprises (SMMEs) in the North West Province. The study adopted qualitative and quantitative research approaches (mixed method). A non-probability, convenience sample of 82 participants were used from a population of 140 SMMEs. For the quantitative part of the study, semi-structured interviews were conducted by the researcher in order to gather information about the support services that the North West Development Corporation offers. SMMEs indicated uncertainty about being aware of the support services offered by NWDC. The findings of the study show that the marketing of the NWDC is not reaching the targeted audience at an acceptable level. The study can conclude that a significant number of the SMMEs do not have the required awareness of the NWDC's support services. It is recommended from the study that good strategic marketing communication will encourage organisational sustainability which will also be beneficial to future SMME entrepreneurs and the economic development of the region.
\end{abstract}

Keywords: Developmental Corporations; North West Development Corporation; Small, Medium and Micro Enterprises (SMMEs); Strategic Marketing Communication

\section{INTRODUCTION}

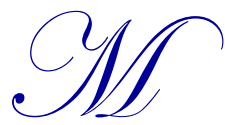

arketing is currently regarded as an essential set of principles and practices which are necessary in order to attract and retain customers. Furthermore, strategic marketing communication is imperative for the successful implementation of projects of developmental corporations. Developmental corporations are faced with situations where it is necessary to meet their customers' (i.e. SMMEs) needs satisfactorily and to help create competitive advantageous that will ensure the long-term survival of the SMMEs they are supporting (Fadahunsi \& Pelser, 2013). This study was aimed at determining whether effective strategic marketing communication exists between the North West Development Corporation (NWDC) and all their registered Small, Medium and Micro Enterprises (SMMEs) in the North West Province. The NWDC in the North West Province of South Africa, has its head office situated in Mafikeng and is primarily there to foster SMME business development. The Corporation operates within all four regions of the North West Province namely Ngaka Modiri Molema region, Dr Ruth Mompati region, Bojanala region and Dr Kenneth Kaunda region (NWDC, 2010).

According to Fohtung, Fongwa, Stanley, Molem, Okezie, Oneal \& Idoku. (2012), SMMEs are being perceived as clients rather than beneficiaries of support services, hence there is a very low level of awareness by SMMEs regarding the various support services that are available for them. "Creating the channels for effective collaboration between stakeholders is essential as many Development Agencies and related partners can often become overwhelmed by their workloads, leaving little time for communication" (Mountford, 2009). 
The aims and objectives of the NWDC are to plan, finance, co-ordinate, promote and carry out the economic development of the province and its people in the commercial fields of industry, commerce, finance, mining and other business, resulting in wealth and job creation (NWDC, 2010). Effective communication of the NWDC's support services to Small Medium and Micro Enterprises (SMMEs) remains a challenge. As indicated by Nedlac (2005) "there is lack of awareness of available support, in terms of information". Gounden, (2000) also states that there are core difficulties seen in SMMEs accessing information and a lack of market exposure.

\section{LITERATURE REVIEW}

Marketing plays a significant role in any organisation. According to Kotler and Keller (2006) marketing is everywhere and good marketing is no accident, but a consequence of cautious planning and execution that deals with identifying and meeting individual and social needs. Marketing is defined as an exchange between an organisation and its customers. The customer wants something from the firm and the firm wants something from the customer hence marketers try to figure out what customers want and how to provide it profitably (Iacobucci, 2012). Kotler and Keller (2012) state one of the shortest definitions of marketing as "meeting needs profitably".

According to Cant and Van Heerden (2010) marketing contributes to the achievement of the fundamental objectives of most businesses, which include survival, profitability and growth. The marketing mix combines product, distribution (place), marketing communication and pricing strategies in a way that creates exchanges satisfying to both the individual's and company objectives (Cant \& Van Heerden, 2010).

\section{Corporate Marketing}

Corporate marketing activities are publicly visible programmes and actions that companies undertake to communicate corporate activities that reflect the social responsibility, values and goals of the company (Wilson, 2001). According to the NWDC (2010) the vision of the North West Development Corporation (Pty) Ltd is for the NWDC brand to be recognised as an efficient and effective economic development agency within the North West Province.

The strategic objectives of the NWDC with regard to SMMEs are to:

- $\quad$ Establish strategic partnerships with both public and private sector institutions in order to draw on their relevant expertise and resources for the benefit of the manufacturing, trade and SMME sectors throughout the Province.

- $\quad$ Facilitate access to business opportunities, financing and other resources by SMMEs in order to prepare them for the future.

- $\quad$ Provide affordable infrastructure for SMMEs desiring to operate as small industries.

- $\quad$ Identify markets and strategic partners for SMMEs.

\section{Marketing Communication}

According to Belch and Belch (2007) the marketing communication purpose in most companies was dominated by mass media advertising for many years. The majority of marketers used additional marketing communication tools. Sales promotion and direct marketing agencies as well as package design firms, were generally viewed as supporting services and often used on an impromptu or a per project basis. These companies fail to recognise that the wide range of marketing communication tools available must be coordinated to communicate effectively and present a consistent image to target markets.

Customers should be made aware of what the organisation has to offer, hence almost all firms selling a product or a service use some form of advertising. Advertising is any form of paid communication in which the sponsor or firm is identified. Traditional media such as television, radio, newspapers, magazines, books, direct mail, billboards and transit cards (advertisements on buses and taxis and at bus stops) are commonly used to transmit advertisements to customers (Belch and Belch, 2007). 
One of the most important reasons for the growing importance of marketing communication is that it plays a key role in the process of developing and sustaining a consistent image in the market. With more products and services competing for consideration by customers who have less time to make choices, well known brands have a major competitive advantage in the marketplace (Prinsloo, Groenewald \& Pelser, 2014).

A brand should represent what an organisation is about (company personality) or has to offer. Beukes, Prinsloo \& Pelser, (2013) states that a brand is a sign of identification, the label which differentiates the product from the competitors. A strong brand is a business asset and delivers outstanding benefits. It commands a premium price and makes marketing more efficient. Wood (2000) continues to define a brand as a name, term, sign, symbol, or design, or a combination of them, intended to identify the goods or services of one seller or group of sellers and to differentiate them from those of competitors.

Thus, the NWDC brand has to be communicated to all SMMEs (registered and non-registered) for them to be aware of how they can benefit from it.

\section{Brand Identity}

Capon and Hulbert (2007) define brand identity as the associations an organisation wants people to hold about its brand. Iacobucci (2012) states that regardless of the quantity of information inherent in the brand name when it is introduced to the market place, brand name meaning is built over time through the firm's communications to customers. The marketer educates customers about the meaning of the brand as well as its logos and symbols. Just as the brand name engages the customers verbally, the logos and packaging colours engage the customers visually and sensually (Beukes et al., 2013).

Understanding brand meaning involves understanding the symbolism and associations that create brand image, the mental impression consumers construct for a product. The richness of the brand image determines the quality of the relationship and the strength of the associations and emotional connections that link a customer to a brand (Prinsloo, et al., 2014). Branding should be the cornerstone of the NWDC's marketing efforts toward SMMEs in the relevant region or regions.

\section{Small, Medium and Micro Enterprises (SMMEs)}

SMMEs exist in many economies. SMMEs are universally acknowledged as the driving force of economies in both developed and developing nations (Fadahunsi \& Pelser, 2013). According to Biekpe (2011) the role of SMMEs in the economy is to increase productivity, create employment especially for unskilled labour, and help reduce poverty.

Nieman, Hough \& Nieuwenhuizen (2004) define a small business as one that is independently owned and operated, but is not dominant in its field and does not engage in any new marketing or innovative practices. The label 'small business' is attributed to businesses that meet the following criteria:

"Financing of the business is supplied by one individual or a small group of individuals; apart from its marketing function, the business operations are geographically restricted; compared to the bigger firms in the industry, the business is small and the number of employees in the business is usually less than 100." Longnecker, Moore \& Petty, 2005:14. 
According to South Africa's National Small Business Act 102 of 1996, Small, Medium and Micro Enterprises are defined as follows (South Africa, 2004):

- Survivalist Enterprises - which operate in the informal sector of the economy, mainly undertaken by unemployed persons whose income is generated below the poverty line, providing minimum means to keep the unemployed and their families alive. Little capital is invested with not much assets, neither is there much training. Opportunities for growing these businesses are very small.

- $\quad$ Micro Enterprises - there are between one to five employees, usually the owner and family. They are informal with no license, formal business premises, or labour legislation. Turnover is below the VAT registration level of R300 000 per year. The owner has basic business skills and training and the business has the potential to make the transition to a viable formal small business.

- Very Small Enterprise - is part of the formal economy with the use of technology and has less than 10 paid employees. Includes self-employed artisans (electricians, plumbers) and professionals.

- $\quad$ Small Enterprise - as less than 100 employees. It is more established than very small enterprises. It is formal and registered, with fixed business premises. Owner manages, but has a more complex management structure.

- $\quad$ Medium Enterprise - as up to 200 employees and still mainly owner managed, but has a decentralised management structure with division of labour. It operates from fixed premises with all formal requirements.

\section{PROBLEM STATEMENT}

The NWDC, previously known as the Bophuthatswana National Development Corporation (BNDC), was established and owned by the former Republic of Bophuthatswana as its economic development agency. The mission of the BNDC was to contribute towards the improvement of the quality of life in Bophuthatswana by developing Industry, Commerce, Small Businesses and Human Resources (NWDC, 2010). After the reincorporation of the former Republic of Bophuthatswana into the Republic of South Africa, the North West Provincial Government recognised the need for the continuance of the former BNDC as a development corporation for the North West Province (NWDC, 2010).

The NWDC came into existence when the North West Development Corporation Limited Act (Act No 6 of 1995), was approved by the Provincial Legislature and published in the North West Provincial Gazette during 1995. Due to various constraints the NWDC was placed under judicial management and as part of the business rescue plan, the NWDC was later converted into a private company by the judicial managers on 3 February 1999, named the North West Development Corporation (Pty) Ltd. The vision of NWDC is for the NWDC brand to be recognised as that of an efficient and effective economic development agency within the North West Province (NWDC, 2010).

According to the NWDC's marketing, communication and social responsibility policy (NWDC, 2012) the marketing and communication department of the NWDC takes responsibility for the marketing function of the NWDC. The department's functions include the marketing of the NWDC brand, by corporate image management with respect to NWDC stakeholders, and by marketing the NWDC through communication. This should create brand loyalty and support in the form of corporate social responsibility initiatives which are informed by the NWDC value system.

The objective of the marketing of the NWDC brand is to expand the NWDC corporate brand within the North West Province, which includes businesses, industry and the public, as well as to create an awareness of the NWDC amongst potential investors outside of the North West Province (NWDC, 2012).

Strategic marketing communication is imperative for implementation of the projects at NWDC. Business development in the North West Province, however, seems to be hampered by the lack of effective marketing communication from the NWDC regarding its support services and the lack of feedback from the registered SMMEs regarding their satisfaction with services rendered. 


\section{RESEARCH OBJECTIVES \& QUESTIONS}

The research objectives are as follows:

- $\quad$ To identify the marketing communication challenges of the NWDC.

- To determine the effectiveness of the marketing communication of the NWDC's support services to SMMEs.

- $\quad$ To establish the level of awareness of NWDC's support services amongst the SMMEs.

- To make suggestions that address the identified marketing communication challenges of the NWDC to SMMEs.

The study focuses on three central questions:

1. Is the NWDC's marketing communication effective?

2. To what extent are the SMMEs aware of the NWDC's marketing support services?

3. How can the NWDC effectively use marketing communication?

\section{RESEARCH METHODOLOGY}

The empirical focus was in the Ngaka Modiri Molema region since it encapsulates the capital city of the Province and has the highest population of registered SMME. The study adopted qualitative and quantitative research approaches (mixed method). A mixed method approach was advantageous in the sense that it enabled the researcher to simultaneously answer confirmatory and exploratory questions therefore verifying and generating theory in the same study (Tashakkori \& Teddlie, 2003), hence qualitative and quantitative data was collected, and the research was explorative in nature. The purpose of the qualitative approach in this research was to explore the support services and the levels of communication that are offered by NWDC.

The population $(\mathrm{N}=140)$ consisted of all registered SMMEs on the current database. 108 SMMEs (convenience sampling) constituted the sample (n) for the study using a 0.05 margin of error. The population for this study comprised all the SMMEs in the Mafikeng and Zeerust areas (77 and 63 respectively) that are registered with NWDC and have their business in the current NWDC industrial sites. The participants (SMMEs) also had to show an interest or willingness to participate in the study. The non-probability sampling type was appropriate for this study as the convenience sampling method was adopted, based on the availability of SMMEs $(n=82)$.

For this study a list of all SMMEs registered with NWDC in Mafikeng and Zeerust (Lehurutse and Motswedi village) was retrieved from the NWDC database and this constituted the population. Data was collected at the NWDC offices in Mafikeng. Two officials from the NWDC head office in Mafikeng and one official from the NWDC Regional Office in Mafikeng were interviewed. Questions for the interviews were divided into three themes:

- $\quad$ The extent of awareness by SMMEs of NWDC's marketing support services.

- $\quad$ The effectiveness of the NWDC's marketing communication.

- $\quad$ How marketing communication is effectively used by the NWDC.

For the quantitative part of the study, semi-structured interviews were conducted by the researcher in order to gather information about the support services that the North West Development Corporation offers. A list of perceptual attributes of the NWDC was identified from the interviews held with the employees of NWDC. The questionnaire was thereafter developed in a way that SMMEs had to indicate their level of awareness with regards to the support services offered by NWDC. The questionnaire comprised Section A that had demographics and personal data. Section B required business data information. Section C consisted of questions that focused on the awareness of support services and communication levels and was divided into Parts $\mathrm{A}$ and $\mathrm{B}$. Participants were asked to answer Part A according to a 5 point Likert scale. Part B had two closed questions.

The study compared the analysis of SMME data with the analysis of NWDC employee data. The very same questionnaire was distributed to a sample of NWDC employees working with SMMEs in order to rate the services 
they offer SMMEs. The questionnaire to NWDC employees had Section A that highlighted Demographics and Section B that addressed the awareness of support services. Communication levels consisted of Part A (5 point Likert scale) and Part B (2 closed questions).

\section{Validity \& Reliability}

The validity of the questionnaire was tested by carrying out a pilot study that employed factor analysis to confirm that the questions were formulated to measure the support services offered by NWDC. A pilot study was done to serve as a testing ground for data collection instruments, sample selection and the method of analysis. Questionnaires were distributed to 10 SMMEs and their feedback revealed that they did not experience any difficulties in providing answers to the questions.

Field (2007) reasons that with attitudinal or behavioural constructs, an alpha coefficient above 0.70 is sufficient and that such data is suitable to use for subsequent analytical scrutiny. All the participants (SMMEs) responses were used to determine the reliability of the extracted factor. The Cronbach alpha coefficient measured a very respectable 0.959 for the study.

\section{Ethical Considerations}

The following ethical considerations were adhered to:

- Guarantee of confidentiality.

- The principle of voluntary participation.

Permission to conduct the study was sought and granted by the North West Development Corporation. Ethical approval for the study was obtained from the ethics committee of the North West University, Mafikeng Campus.

\section{ANALYSIS OF RESULTS}

\section{Descriptive Statistics}

According to Figure 1, 12.2\% of the SMMEs are in the construction business. The aggregate of SMMEs that provide services are $18.3 \%$ and the aggregate of SMMEs that provide products are $81.74 \%$. This indicates that the business of selling goods is a focus area for SMME owners. 


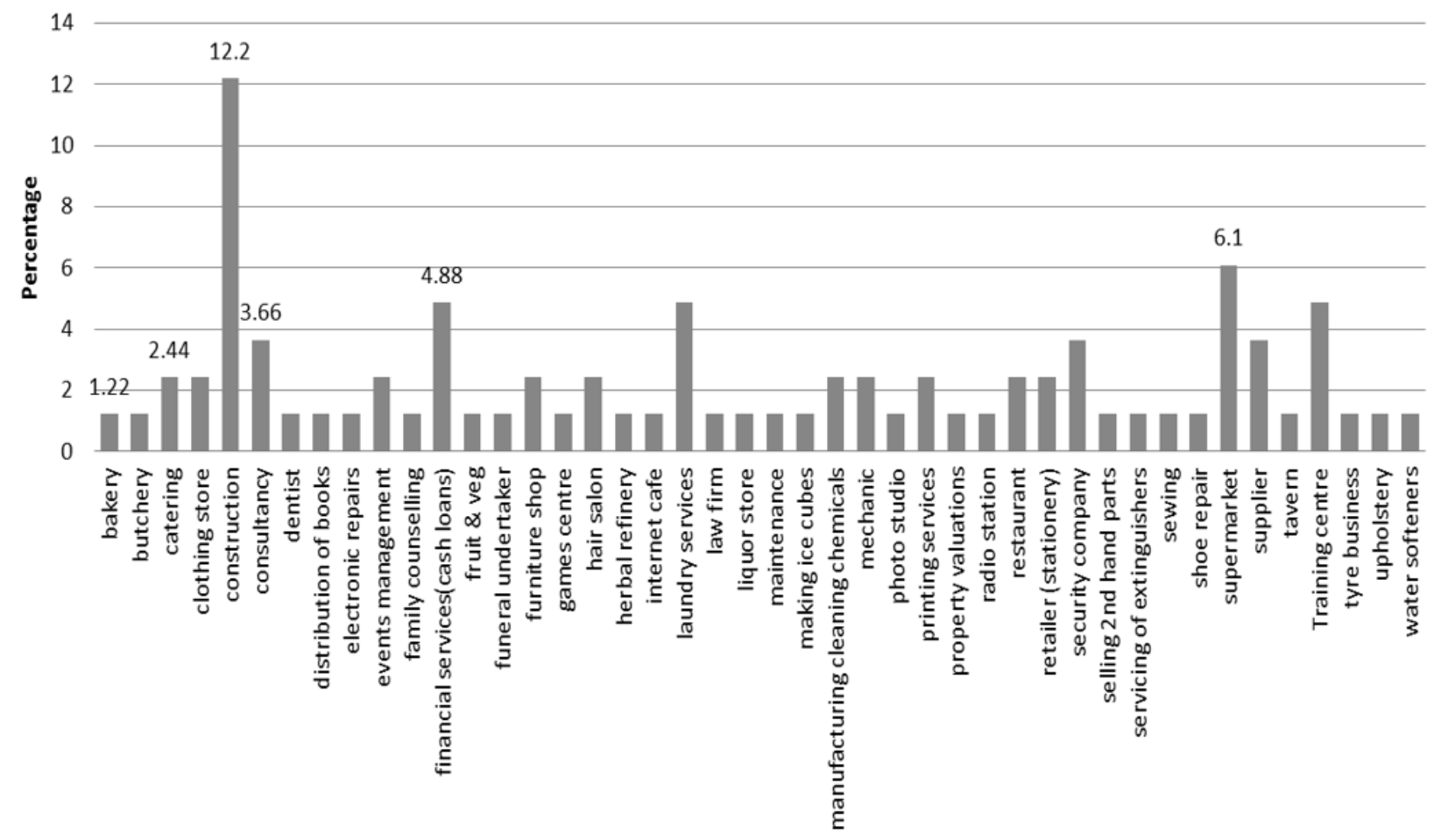

Figure 1: Business Type Profile

Further to the results, 59.75\% of the SMMEs are selling other products which refer to miscellaneous items while $1.22 \%$ of the SMMEs indicated as selling products under the category of unsought products. This result reflects that SMMEs are selling a fairly wide variety of goods. Finally, $84.15 \%$ of the SMMEs indicated that they do not make use of the World Wide Web, also known as the internet for general communication with the NWDC. $15.85 \%$ of the SMMEs on the other hand make use of the internet. This is an indication that the majority of the SMMEs have not implemented technology for communication purposes with the NWDC.

Table 1 shows the items of the Likert scale showing mean values and the standard deviation. The Likert scale items were coded as follows: $1=$ strongly disagree, $2=$ Disagree, $3=$ Unsure, $4=$ Agree and $5=$ strongly agree. Statement 1 in Table 1, "a vibrant SMME sector is crucial for South Africa's economic growth, industrial development and job creation" indicated the largest mean of 3.90 (rounded up to 4) which shows that the SMMEs are in agreement with this statement because 4 in the Likert scale coding indicates "agree". Statement 5 (b) in Table 1, "exhibitions" indicated the lowest mean of 2.21 (rounded down to 2) which shows that SMMEs disagree that they have a comprehensive awareness of NWDC's training to SMME's by presenting programmes such as exhibitions and 2, according to the Likert scale coding, indicates "disagree". In aggregate the items in the Likert scale obtained an average of 2.60. Therefore with regards to awareness of support services and communication levels the SMMEs indicated that they are unsure. This is arrived at after rounding 2.60 up to 3 and according to the Likert scale coding 3 indicates an "unsure" response.

The Likert scale standard deviation of 0.96 was obtained (Table 1). Therefore with regards to awareness of support services and communication levels, the SMME responses are almost the same or identical concerning their awareness of NWDCs support services. It indicates that the scores are closely clustered around the mean. 
Table 1: Awareness of Support Services and Communication Levels

\begin{tabular}{|c|c|c|c|}
\hline & & \multicolumn{2}{|c|}{ Likert Scale } \\
\hline & Item & Mean & Standard Deviation \\
\hline 1 & $\begin{array}{l}\text { A vibrant SMME sector is crucial for South Africa's } \\
\text { economic growth, industrial development and job } \\
\text { creation. }\end{array}$ & 3.90 & 0.94 \\
\hline 2 & $\begin{array}{l}\text { SMMEs in the North West Province have easy access to } \\
\text { affordable and appropriate finance. }\end{array}$ & 2.63 & 0.95 \\
\hline 3 & $\begin{array}{l}\text { SMMEs that receive business development services are } \\
\text { better positioned to access finance easily. }\end{array}$ & 3.02 & 0.99 \\
\hline \multirow[t]{9}{*}{4} & \multicolumn{3}{|c|}{ You have a comprehensive awareness of all the support services that NWDC has to offer such as: } \\
\hline & a) Loan service. & 2.60 & 1.05 \\
\hline & b) Mentorship. & 2.30 & 0.90 \\
\hline & c) Registration of companies & 2.85 & 1.02 \\
\hline & d) Pre care and after care service. & 2.46 & 0.98 \\
\hline & $\begin{array}{l}\text { e) Development opportunity by allocating business } \\
\text { space. }\end{array}$ & 3.32 & 1.09 \\
\hline & f) $\quad$ Mentorship from stage 1 & 2.24 & 0.84 \\
\hline & g) Moratorium on loans. & 2.37 & 0.91 \\
\hline & h) Negotiations on rental. & 2.89 & 1.11 \\
\hline \multirow[t]{5}{*}{5} & \multicolumn{3}{|c|}{ You have a comprehensive awareness of NWDC's training to SMME's by presenting programmes such as: } \\
\hline & a) Workshops on loan taking. & 2.24 & 0.90 \\
\hline & b) Exhibitions. & 2.21 & 0.87 \\
\hline & c) Business plan drafting. & 2.24 & 0.87 \\
\hline & d) Report writing & 2.24 & 0.87 \\
\hline 6 & $\begin{array}{l}\text { Assistance with finding a suitable market for your } \\
\text { products or services. }\end{array}$ & 2.33 & 0.93 \\
\hline 7 & $\begin{array}{l}\text { NWDC plays an active role in promoting your business } \\
\text { and contributing to its growth. }\end{array}$ & 2.35 & 0.99 \\
\hline 8 & $\begin{array}{l}\text { Good communication relationship with the NWDC is in } \\
\text { existence. }\end{array}$ & 3.15 & 1.13 \\
\hline \multirow[t]{12}{*}{9} & \multicolumn{3}{|c|}{ You have a comprehensive awareness of communication methods used by NWDC such as: } \\
\hline & a) Phone calls. & 2.89 & 1.07 \\
\hline & b) Brochures. & 2.55 & 1.03 \\
\hline & c) Email. & 2.62 & 1.00 \\
\hline & d) Workshops. & 2.48 & 0.91 \\
\hline & e) Newspaper article. & 2.48 & 0.92 \\
\hline & f) Meetings. & 2.55 & 0.98 \\
\hline & g) Site visits. & 2.71 & 1.09 \\
\hline & h) Exhibitions. & 2.37 & 0.87 \\
\hline & i) Noticeboards. & 2.46 & 0.93 \\
\hline & j) Newsletters. & 2.49 & 0.91 \\
\hline & k) Memos. & 2.46 & 0.89 \\
\hline 10 & $\begin{array}{l}\text { The NWDC engages with you online/ internet by sending } \\
\text { you emails to keep you updated. }\end{array}$ & 2.49 & 0.98 \\
\hline & Average & 2.60 & 0.96 \\
\hline
\end{tabular}

The average responses (see Figure 2) in terms of percentages on awareness of support services and communication levels indicated that $35.61 \%$ of the SMMEs disagree that they are aware of support services offered by NWDC. $3.25 \%$ of the SMMEs strongly agree that they are aware of the support services offered by NWDC. This indicates that SMMEs are uninformed about NWDCs support services. 


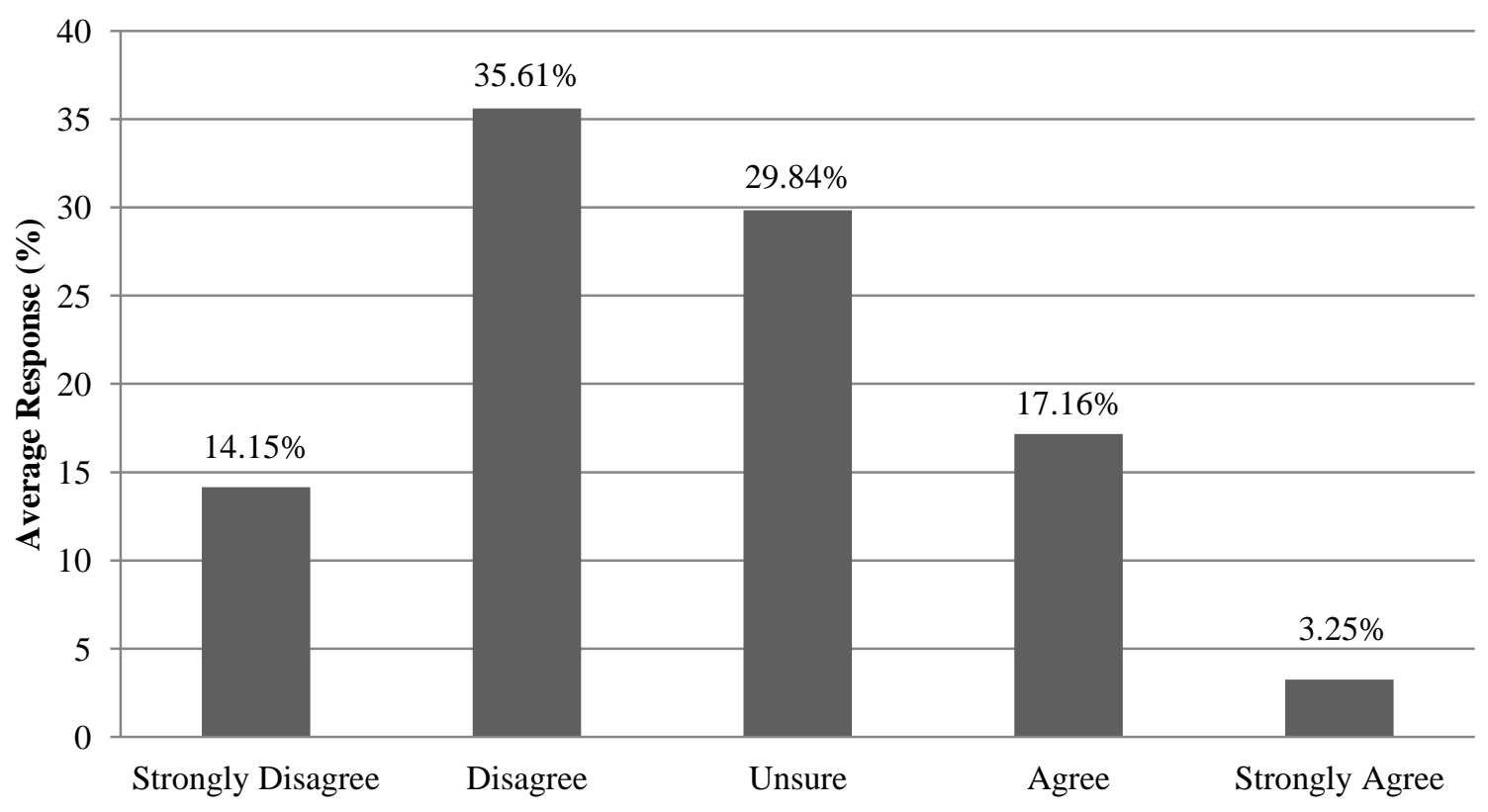

Figure 2: Views on Awareness of Support Services and Communication Levels

To conclude this section, $85.37 \%$ of the SMMEs indicated that workshops and exhibitions are never held. $1.22 \%$ of the SMMEs indicated that workshops and exhibitions are held twice a month. It seems that the majority of the SMMEs have not attended any workshops or exhibitions held by NWDC. $43.90 \%$ of SMMEs indicated that the NWDC communicates with them once a month by site visits regarding SMME queries and progress. $1.22 \%$ of the SMMEs indicated that NWDC communicated with them 4-6 times a month by site visits. Finally, there was a $43.9 \%$ - 39.02\% split between SMMEs that indicated "once a month" and SMMEs that indicated "never".

\section{Test of Significance}

The Spearman's rank correlation was used to analyse perceptions between age category and views of SMMEs on awareness of support services and communication levels (see Table 2). Since the p-values of 0.035 and 0.010 are less than a level of significance of 0.050 , the correlation between age category and views of SMMEs on awareness of support services and communication levels is significant. Positive correlation coefficients $(r=0.234$ and 0.285 ) imply that older SMMEs tend to agree with the items listed in Table 2, whereas younger SMMEs tend to disagree.

Table 2: Correlation between Age Category and Views of SMMES on Awareness of Support Services and Communication Levels

\begin{tabular}{|l|l|c|}
\hline $\begin{array}{l}\text { You have a comprehensive awareness of all the support } \\
\text { services that NWDC has to offer such as: }\end{array}$ & & Age Category \\
\hline \multirow{2}{*}{ Mentorship } & Correlation coefficient (r) & 0.234 \\
\cline { 2 - 3 } & $\mathrm{p}$ - value & 0.035 \\
\hline \multirow{2}{*}{ Moratorium on loans } & Correlation coefficient (r) & 0.285 \\
\cline { 2 - 3 } & $\mathrm{p}$ - value & 0.010 \\
\hline
\end{tabular}

\section{Factor Analysis}

Principal factors extraction with varimax rotation was performed on 30 items from a sample of 82 SMMEs. Principal components extraction was used prior to principal factors extraction to estimate number of factors, presence of outliers, absence of multicollinearity and factorability of the correlation matrices. Thereafter the "varimax rotation method" was used to detect factors each of which is related to few variables. The first factor solution was stage one where a set of loadings was calculated that yielded theoretical variances and covariances. 
Table 3 reflects the principal components extraction method that utilizes the entire variation in the set of variables being analyzed. The eigenvalues indicates the amount of variance explained by each component. The total variance was used to determine the emerging components. These components are the five whose eigenvalue is greater than 1 as indicated in Table 3 (highlighted in bold) under the column total (eigenvalues). They have values of $15.083,3.140,1.701,1.271$ and 1.084 .

Table 3: Principal Components Extraction Method

\begin{tabular}{|c|c|c|c|c|c|c|}
\hline \multirow[b]{2}{*}{ Component } & \multicolumn{3}{|c|}{ Initial Eigenvalues } & \multicolumn{3}{|c|}{ Rotation Sums of Squared Loadings } \\
\hline & $\begin{array}{c}\text { Total } \\
\text { (Eigenvalues) }\end{array}$ & $\%$ of Variance & Cumulative \% & Total & $\%$ of Variance & Cumulative \% \\
\hline 1 & 15.083 & 50.278 & 50.278 & 9.124 & 30.414 & 30.414 \\
\hline 2 & 3.140 & 10.468 & 60.746 & 7.879 & 26.263 & 56.678 \\
\hline 3 & 1.701 & 5.671 & 66.417 & 2.394 & 7.980 & 64.657 \\
\hline 4 & 1.271 & 4.236 & 70.653 & 1.588 & 5.294 & 69.951 \\
\hline 5 & 1.084 & 3.614 & 74.267 & 1.295 & 4.316 & 74.267 \\
\hline 6 & .997 & 3.324 & 77.591 & & & \\
\hline 7 & .860 & 2.868 & 80.459 & & & \\
\hline 8 & .784 & 2.612 & 83.071 & & & \\
\hline 9 & .688 & 2.293 & 85.365 & & & \\
\hline 10 & .540 & 1.800 & 87.165 & & & \\
\hline 11 & .480 & 1.601 & 88.765 & & & \\
\hline 12 & .471 & 1.570 & 90.335 & & & \\
\hline 13 & .400 & 1.333 & 91.669 & & & \\
\hline 14 & .353 & 1.176 & 92.845 & & & \\
\hline 15 & .321 & 1.072 & 93.916 & & & \\
\hline 16 & .274 & .913 & 94.829 & & & \\
\hline 17 & .230 & .767 & 95.596 & & & \\
\hline 18 & .222 & .739 & 96.335 & & & \\
\hline 19 & .208 & .692 & 97.027 & & & \\
\hline 20 & .176 & .588 & 97.616 & & & \\
\hline 21 & .152 & .506 & 98.122 & & & \\
\hline 22 & .141 & .470 & 98.592 & & & \\
\hline 23 & .099 & .331 & 98.923 & & & \\
\hline 24 & .084 & .279 & 99.202 & & & \\
\hline 25 & .064 & .214 & 99.416 & & & \\
\hline 26 & .057 & .189 & 99.605 & & & \\
\hline 27 & .050 & .166 & 99.771 & & & \\
\hline 28 & .032 & .107 & 99.878 & & & \\
\hline 29 & .021 & .069 & 99.948 & & & \\
\hline 30 & .016 & .052 & 100.000 & & & \\
\hline
\end{tabular}

Table 4 shows variables (Y) that can be explained by the five components identified. According to Raul and Ahmed (2005:273) the factor loading worth considering from the rotated factor matrix should be greater than 0.45. Therefore the variables with loadings of 0.45 or greater in the table will be the points to be considered for inclusion of a variable in interpretation of a factor. 
Table 4: Rotated Component Matrix

\begin{tabular}{|c|c|c|c|c|c|}
\hline \multirow[t]{2}{*}{ Variables } & \multicolumn{5}{|c|}{ Factor/Component } \\
\hline & F1 & F2 & F3 & F4 & F5 \\
\hline Y1 & .105 & -.025 & .005 & -.047 & .886 \\
\hline Y2 & .118 & .372 & .052 & .747 & -.239 \\
\hline Y3 & .238 & .367 & -.008 & .561 & .272 \\
\hline Y4 & .143 & .572 & .573 & .149 & .141 \\
\hline Y5 & .340 & .782 & .254 & -.010 & .034 \\
\hline Y6 & .128 & .296 & .682 & -.080 & -.012 \\
\hline Y7 & .390 & .645 & .227 & .050 & -.057 \\
\hline Y8 & -.003 & .095 & .853 & .054 & .022 \\
\hline Y9 & .296 & .799 & .208 & .042 & -.040 \\
\hline Y10 & .173 & .690 & .342 & .142 & .251 \\
\hline Y11 & .242 & .515 & .386 & -.259 & -.310 \\
\hline Y12 & .335 & .822 & .064 & .184 & -.067 \\
\hline Y13 & .251 & .836 & .068 & .260 & .009 \\
\hline Y14 & .250 & .840 & .073 & .107 & -.038 \\
\hline Y15 & .373 & .712 & .162 & .052 & -.033 \\
\hline Y16 & .301 & .694 & .112 & .357 & -.036 \\
\hline Y17 & .296 & .647 & .040 & .303 & -.029 \\
\hline Y18 & .464 & .143 & .458 & .129 & -.264 \\
\hline Y19 & .786 & .014 & .245 & .137 & -.092 \\
\hline Y20 & .783 & .202 & .182 & .114 & .070 \\
\hline Y21 & .769 & .330 & .136 & .183 & .123 \\
\hline Y22 & .833 & .451 & .036 & -.009 & .147 \\
\hline Y23 & .822 & .468 & .019 & .039 & .126 \\
\hline $\mathrm{Y} 24$ & .832 & .278 & .136 & -.082 & .064 \\
\hline Y25 & .778 & .198 & .194 & .201 & -.071 \\
\hline Y26 & .839 & .359 & -.002 & .124 & .081 \\
\hline Y27 & .841 & .439 & .060 & .034 & .123 \\
\hline Y28 & .833 & .338 & -.038 & -.004 & -.121 \\
\hline Y29 & .841 & .348 & -.061 & -.098 & -.056 \\
\hline $\mathrm{Y} 30$ & .699 & .138 & .047 & .314 & -.002 \\
\hline
\end{tabular}

Five factors were extracted with a cut off of 0.45 for inclusion of a variable in the interpretation of those factors. All the factors were included in the interpretation. Loading of variables on factors, communalities and percentages of variance are shown in Table 4 under Factors F1 to F5 respectively.

Table 5 shows the order in which variables contribute to factors and lists the factors after rotation of components. 
Table 5: Order in which Variables Contribute to Factors

\begin{tabular}{|c|c|c|c|c|c|}
\hline & Factor 1 & Factor 2 & Factor 3 & Factor 4 & Factor 5 \\
\hline & COMMUNICATION & MENTORSHIP & $\begin{array}{l}\text { REGISTRATION } \\
\text { OF COMPANIES }\end{array}$ & $\begin{array}{c}\text { ACCESS TO } \\
\text { FINANCE }\end{array}$ & $\begin{array}{c}\text { DEVELOPMENT } \\
\text { OF SMMES }\end{array}$ \\
\hline 1 & $\begin{array}{l}\text { Good communication } \\
\text { relationship with the } \\
\text { NWDC is in existence }\end{array}$ & Loan service & Loan service & $\begin{array}{l}\text { SMMEs in the North } \\
\text { West Province have easy } \\
\text { access to affordable and } \\
\text { appropriate finance }\end{array}$ & $\begin{array}{l}\text { A vibrant SMME sector } \\
\text { is crucial for South } \\
\text { Africa's economic } \\
\text { growth and job creation }\end{array}$ \\
\hline 2 & Phone calls & Mentorship & $\begin{array}{l}\text { Registration of } \\
\text { companies }\end{array}$ & $\begin{array}{l}\text { SMMEs that receive } \\
\text { business development } \\
\text { services are better } \\
\text { positioned to access } \\
\text { finance easily }\end{array}$ & \\
\hline 3 & Brochures & $\begin{array}{l}\text { Pre - care and } \\
\text { after care service }\end{array}$ & $\begin{array}{l}\text { Development } \\
\text { opportunity by } \\
\text { allocating business } \\
\text { space }\end{array}$ & & \\
\hline 4 & Email & Mentorship & $\begin{array}{l}\text { Good } \\
\text { communication } \\
\text { relationship with } \\
\text { the NWDC is in } \\
\text { existence }\end{array}$ & & \\
\hline 5 & Workshops & $\begin{array}{l}\text { Moratorium on } \\
\text { loans }\end{array}$ & & & \\
\hline 6 & Newspaper article & $\begin{array}{l}\text { Negotiations on } \\
\text { rental }\end{array}$ & & & \\
\hline 7 & Meetings & $\begin{array}{l}\text { Workshops on } \\
\text { loan taking }\end{array}$ & & & \\
\hline 8 & Site visits & Exhibitions & & & \\
\hline 9 & Exhibitions & $\begin{array}{l}\text { Business plan } \\
\text { drafting }\end{array}$ & & & \\
\hline $\begin{array}{l}1 \\
0\end{array}$ & Noticeboards & Report writing & & & \\
\hline $\begin{array}{l}1 \\
1\end{array}$ & Newsletters & $\begin{array}{l}\text { Assistance with } \\
\text { finding a suitable } \\
\text { market for your } \\
\text { products or } \\
\text { services }\end{array}$ & & & \\
\hline $\begin{array}{l}1 \\
2\end{array}$ & Memos & $\begin{array}{l}\text { NWDC plays an } \\
\text { active role in } \\
\text { promoting your } \\
\text { business and } \\
\text { contributing to } \\
\text { its growth }\end{array}$ & & & \\
\hline $\begin{array}{l}1 \\
3\end{array}$ & $\begin{array}{l}\text { The NWDC engages } \\
\text { with you online / } \\
\text { internet by sending } \\
\text { you emails to keep } \\
\text { you updated }\end{array}$ & Workshops & & & \\
\hline
\end{tabular}

\section{Summary of Findings}

SMMEs indicated uncertainty about being aware of the support services offered by NWDC. The study can conclude that the marketing of the NWDC is not reaching the targeted audience at an acceptable level. Furthermore, $35.61 \%$ of the SMMEs disagreed that they were aware of NWDCs marketing support services whilst $3.25 \%$ of the SMMEs agreed. The study can conclude that a significant number of the SMMEs do not have the required awareness of the NWDC's support services. 
In this research $85.37 \%$ of the SMMEs indicated that they had never attended workshops held by NWDC while $1.22 \%$ agreed they attended workshops twice a month. The study can conclude that the vast majority of the SMMEs have never attended workshops held by NWDC.

Finally, there was a $43.9 \%$ - 39.02\% split between SMMEs that indicated that NWDC communicated through site visits once a month and SMMEs that indicated site visits never took place. The study can conclude that the number of SMMEs that have never had site visits from NWDC is significant but only slightly less than the number of SMMEs that have had site visits.

\section{RECOMMENDATIONS}

\section{Recommendation With Regard To Objective 1}

The uncertainty of SMMEs with regards to NWDC's support services and communication levels is an indication that NWDCs marketing communication message is not effectively communicated to the SMMEs. Therefore, the NWDC must draw up and implement a schedule of specific dates when it will carry out training programmes that it already has in place such as:

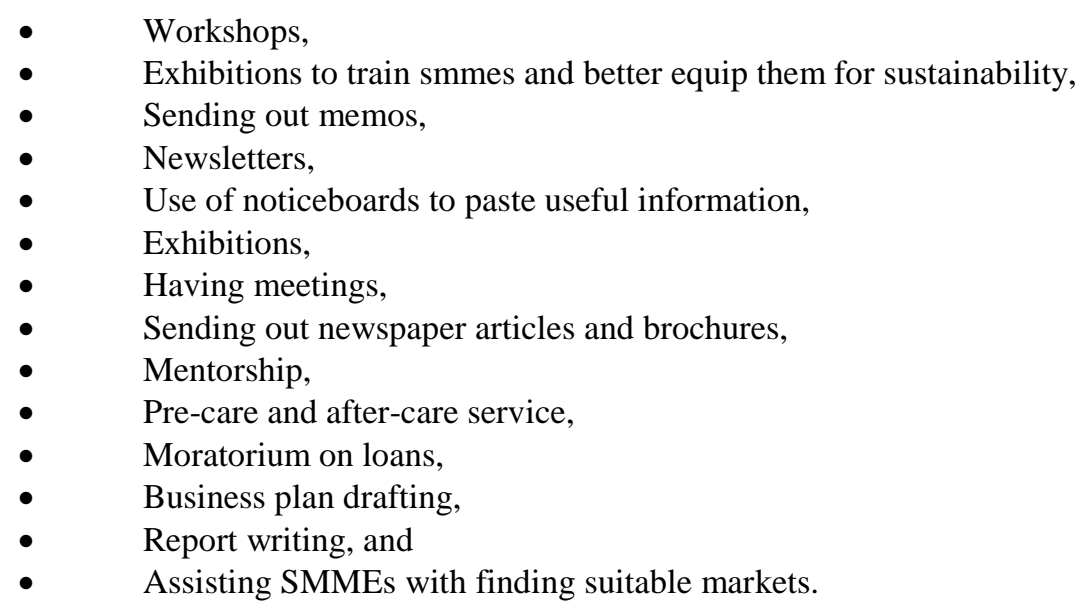

The marketing communication should adopt an action oriented approach towards communicating and working with the SMMEs. According to Beukes et al. (2013) these factors play a very important role in satisfying customer needs and to deliver a service that is of a high quality. For example, the NWDC should communicate relevant information about upcoming training events to the SMMEs for them to plan their time accordingly.

\section{Recommendation With Regard To Objective 2}

The NWDC should encourage its SMMEs to make use of the World Wide Web as this is a technological era. $84.15 \%$ of the SMMEs indicated that they did not make use of the World Wide Web. According to Pelser (2001) technology plays a pivotal role in interactions among the individual, society and nature. technological advances have major effects on each of these entities and are, in turn, influenced by them. Management of technology involves developing an understanding of these relationships and dealing with them in a rational and effective manner, and the same applies to marketing communication.

\section{Recommendation With Regard To Objective 3}

The level of awareness amongst SMMEs with regards to NWDC's support services and communication levels was indicated by "unsure" showing that SMMEs are not confident that they are aware of the support services that are being offered to SMMEs. Recent research has shown that setting policies regarding technologies, which have an impact on operations, is the same as developing effective strategies (Pelser, 2014a, 2014b, 2014c, and 
2014d) and therefore it is recommended that a formal marketing communication policy be developed for the NWDC.

\section{Recommendation With Regard To Objective 4}

SMMEs are not well informed about the support services of NWDC and seem hesitant about most of the issues addressed with regards to support services and communication levels. SMMEs view the NWDC mainly as a landlord providing business space and are not provided with support services to an optimum level as should be the case. The North West Development Corporation's mission is to empower and develop SMMEs in the North West Province and therefore the NWDC should expand its marketing perspectives with the view to develop the SMMEs, the North West Province and the people in it.

\section{CONCLUSION}

This study focused on the effectiveness of the strategic marketing communication of the North West Development Corporation to Small, Medium and Micro Enterprises and found that the SMMEs showed uncertainty with regards to their awareness of the NWDC's support services and communication levels. The SMMEs were not supported with strategic marketing communication to enable them towards business growth and business expansion.

There is a need for the NWDC's marketing department to communicate efficiently and effectively with regards to the support services it offers and that are available to the SMMEs. The NWDC's marketing communication should also keep abreast of issues concerning SMMEs so as to provide effective care and continuous support to the SMMEs.

Development Corporations should encourage entrepreneurship and optimally use all marketing strategies available for efficient and effective communication. With regard to this study, the NWDC should be in a position to ask for feedback from the relevant SMMEs, as this encourages a dualistic communication process. Good communication will encourage organisational sustainability which will also be beneficial to future SMME entrepreneurs.

It is hoped that the responses from the SMMEs will be used by the NWDC to formulate a strategic marketing policy with the appropriate procedures, which will contribute towards making the process of working with SMMEs positive with regards to entrepreneurship, empowerment and development for the North West Province in South Africa.

\section{AUTHOR INFORMATION}

Inonge Theresa Lisita is currently busy completing her MCom Marketing degree. She started her tertiary education in 2006, enrolling as a pre-graduate at the North-West University, Mafikeng Campus. She completed her BCom Hons in Business Management, graduating in 2011. She also holds an industry position as an innovation project consultant with Innocentrix.

Johannes Jurgens Prinsloo is the Professor in Marketing at the Graduate School of Business and Government Leadership, North-West University, Mafikeng Campus. Prior to his current position he did a marketing internship at the then ISCOR head office in Pretoria and then an international marketer (iron ore) at the same Company. He holds a $\mathrm{PhD}$ in Business Management (Specialization in Sport Marketing) from the Potchefstroom University. His research focus on adventure tourism and sport marketing.

Theuns Pelser is the Director and Strategy Professor of the Graduate School of Business and Government Leadership, North-West University, Mafikeng Campus. Prior to this appointment he was Strategy Manager at Sasol, a petro-chemical multinational company. He holds a $\mathrm{PhD}$ in Strategic Management from the Potchefstroom University. His research focuses on technology strategies, innovation strategies and technology management processes and their relationship to company performance. E-mail: theuns.pelser@nwu.ac.za (corresponding author). 


\section{REFERENCES}

1. Belch, G.E. \& Belch, M.A. (2007). Advertising and promotion: an integrated marketing communications perspective. 7th ed. New York, NY: McGraw-Hill.

2. Beukes, J., Prinsloo, J.J. \& Pelser, T.G. (2013). Service expectations from high- and low-volume customers in the alcoholic beverage industry. Acta Commercii, 13(1), Art. \#172, 8 pages. Retrieved from http://dx.doi.org/10.4102/ac.v13i1.172

3. Biekpe, N. (2011). The voices of SMME's in the South African economy. Retrieved from http://www.dti.gov.za/sme_development/sumit/Small_business_programme.pdf

4. Cant, M.C. \& Van Heerden, C.H. (2010). Marketing management: a South African perspective. Cape Town: Juta \& Co publication.

5. Capon, N. \& Hulbert, J.M. (2007). Managing marketing in the 21st century: developing and implementing the market strategy. 3rd ed. Bronxville, NY: Wossex.

6. Fadahunsi, T. \& Pelser, T.G. (2013). Marketing practices for competitiveness in public further education and training colleges in Gauteng. South African Journal of Higher Education, 27(4) 838-857.

7. Field, A. (2007). Discovering statistics using SPSS. 2nd ed. London: Sage.

8. Fohtung, M.E.F., Fongwa, S., Stanley, E.A., Molem, S., Okezie, G., Oneal, J. \& Idoku U. 2012. Investment climate reforms and the development of SME's: A comparative analysis from South Africa, Cameroon and Nigeria. ICBE-RF Research Report No. 30/12. Dakar: Investment Climate and Business Environment Research Fund.

9. Gounden, S. M. (2000). The impact of the National Department of Public Works' affirmative procurement policy on the participation and growth of affirmable business enterprises in the construction sector. Unpublished PhD thesis. Durban: University of Natal.

10. Iacobucci, D. (2012). Marketing management. Independence, KY: Cengage Learning.

11. Kotler, P. \& Keller, K.L. (2006). Marketing management. 12th ed. Upper Saddle River, NJ: Pearson Prentice Hall.

12. Kotler, P \& Keller, K.L. (2012). A framework for marketing management. 5th ed. England. Upper Saddle River, NJ: Pearson Prentice Hall.

13. Longnecker, J.G., Moore, C.W. \& Petty, J.W. (2005). Small business management: an entrepreneurial emphasis. 13th ed. New York, NY: South Western College.

14. Mountford, D. (2009).Organising for local development: the role of local development agencies. Summary Report, 26-27 November 2009, CFE/LEED, OECD, Retrieved from www.oecd.org/dataoecd/54/41/ 44682618.pdf? contentId $=446$.

15. Nedlac. (2005). Promotion of small and medium enterprises in the South African chemicals sector. Retrieved from: http://www.nedlac.org.za/media/5565/part1.pdf

16. Nieman, G., Hough, J. \& Nieuwenhuizen, C. (2004). Entrepreneurship: a South Africa perspective. Cape Town: Van Schaik.

17. North West Development Corporation. (2010). Small business. Retrieved from http://www.nwdc.co.za/ small-business/

18. North West Development Corporation. (2012). Marketing, communication and social responsibility policy. Retrieved from http://www.nwdc.co.za/wp-content/uploads/2013/11/NWDC-Annual-Report-2012_13elec. copy A037.pdf

19. Pelser, T.G. (2001). A strategic management taxonomy of technology and innovation. Unpublished PhD thesis. Potchefstroom: Potchefstroomse Universiteit vir Christelike Hoër Onderwys.

20. Pelser, T.G. (2014a). Sustaining industry leadership through technology strategy dimensions. Journal of Applied Business Research, 30(3) 763-782.

21. Pelser, T.G. (2014b). The influence of technology strategies and their link to company performance. Mediterranean Journal of Social Sciences, 5(9) 238-247.

22. Pelser, T.G. (2014c). The affect of innovation strategies and their connect to company performance. Mediterranean Journal of Social Sciences, 5(9) 60-68.

23. Pelser, T.G. (2014d). Sustaining industry leadership through innovation strategy archetypes. International Business \& Economics Research Journal, 13(4) 697-714.

24. Prinsloo, J.J., Groenewald, A. \& Pelser, T.G. (2014). Market positioning of branded meat products: a case of the feedlot industry in South Africa. Mediterranean Journal of Social Sciences, 5(1) 129-135. 
25. South Africa. (2004). National Small Business Act 102 of 1996 amended in 2004. Pretoria: Government Printer.

26. Tashakkori, A. \& Teddlie, C. (2003). Handbook of mixed methods in social and behaviour research. Thousand Oaks, CA: Sage.

27. Wilson, A.M. (2001). Understanding organisational culture and the implications for corporate marketing. European Journal of Marketing, 35 (3) 353-367. 